\title{
A CAFONICE VAI AO PARAÍSO: A ARTE DA TROPICÁlIA E OS PRIMEIROS ROMANCES DE MANUEL PUIG.*
}

Lidia Santos**

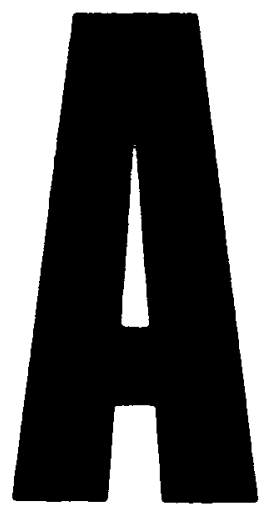

\begin{abstract}
estética dos anos de 1960 , no Brasil, traz, no bojo de suas inovaçōes, o confronto entre o bom e o mau gosto. Mola-mestra das obras tropicalistas, já se prefigura em duas criaçōes de 1967: a instalação Tropicália, de Hélio OITICICA, e o filme Terra em transe, de Glauber ROCHA. Ambas, embora não se ativessem à utilizaçāo do mau-gosto como opção programática, expunham, na sua estrutura, o impasse em que se encontravam as pro-
\end{abstract} postas então vigentes na cultura brasileira. No filme de Glauber, a

* O presente trabalho é fruto de pesquisa realizada a partir do curso Literatura e identidade na América Latina, ministrado pelos professores Irlemar Chiampi e Antonio Dimas, do currículo de Pós-Graduaçáo em Letras da Faculdade de Filosofia, Letras e Ciências Humanas da Universidade de Săo Paulo, (1 semestre de 1989), onde desenvolvemos pesquisa para realização de tese de Doutoramento, sob a orientaçāo da Profe. Irlemar Chiampi, na área de Literatura Hispano-Americana.

* Universidade Federal Fluminense 
política era exposta como uma moda e adquiria, algumas vezes, um tom ridículo e deslocado. Para isso contribuia a concepção de cinema de Glauber, fazendo som e imagem correrem por linhas paralelas, ou seja, sem correspondência. $\mathrm{Na}$ instalaçāo de Oiticica, uma proposta erudita compraz-se em expor imagens óbvias do exotismo brasileiro e elege a televisāo como centro do ambiente, numa também óbvia citação do cotidiano no universo aurático da arte culta. Portanto, antes da justaposição de gostos, faz-se a evidência dos opostos que configuravam uma imagem dispar do Brasil.

$O$ mesmo ano de 1967 assistirá à montagem de $O$ rei da vela, de Oswald de ANDRADE, pelo Teatro Oficina, sob a direçāo de José Celso Martinez Corrêa e cenografia de Hélio Eichebauer que, segundo Edelc io MOSTAÇO, "abusava do kitsch, do pastelão, do verde-amarelo, do mau-gosto." $\mathrm{E}$, também, pelo mesmo grupo, à montagem de Roda-viva, de Chico BUARQUE, espetáculo que, além das características d'O rei da vela, desenvolvia a agressāo ao espectador como forma de reforçar a irrup̧ăo do consumo no cotidiano brasileiro, presente no enredo da peça.

As músicas Alegria, alegria, de Caetano VELOSO, e Domingo no parque, de Gilberto GIL, lançadas em outrubro do mesmo ano na "TV Record, de São Paulo, ampliam a fruição desses procedimentos para o grande público. Os arranjos, realizados pelo músico de formaçāo erudita Rogério Duprat, misturavam elementos cultos (instrumentos clássicos, atonalismos) aos do cotidiano (ruídos de parque de diversōes, vozes) e aos do circuito da cultura popular (berimbau). Logo depois, surge o rótulo Tropicalismo, que é aceito por Caetano e Gil, cedo transformados em astros pelo mercado fonográfico.

Sem ter sido programado como movimento pelos artistas que dele participaram, o Tropicalismo evidencia uma circulaçāo de idéias, uma tentativa, em diversas linguagens, de responder ao impasse de um modelo cultural que já nāo dava conta de expressar a realidade brasileira. Este modelo, construído na ascensão da esquerda derrotada em 1964, continuava a vigorar em 1967. Segundo Roberto SCHWARZ, na época, "apesar da ditadura da direita há relativa hegemonia cultural da esquerda no país." 2 Calcado no populismo, esse modelo se erigira numa exaltação dos valores nacionais. que estariam presentes nas camadas populares. A obra de arte, para ser autêntica, deveria espelhar-se nessas classes e a elas dirigir-se. 1987, p. 72

${ }^{l}$ MOSTAÇO. Edelcio. Do corporal na ante. In: SAFFIOTI FILHO. José et al,

${ }^{2}$ SCHWARZ, Roberto, 1978, p.62 
Daí o tom patemalista do seu engajamento, que se tornara esquemático e, em conseqüência, esteticamente pobre. A esse nacionalismo, - Tropicalismo opunha, além dos elementos citados, uma noção continental da cultura brasileira. Composiçōes como Soy loco por ti, America, de CAPINAM e Gilberto GIL, ao utilizarem a mistura de português e espanhol na sua letra, enquanto utilizam a rumba como ritmo e o gingado caribenho como interpretação, não deixam dúvida quanto à latino-americanidade da cultura brasileira presente em suas propostas. Note-se que a Revolução Cubana e a guerrilha, já citada na letra de Alegria, alegria, começa a crescer no Brásil e avança, à mesma época, em toda a América Latina.

Neste mesmo ano, o cinema comparece com $O$ bandido da luz vermelha, de Rogério Sganzerla. Também em 1968, a música popular do Tropicalismo conhece a sua maior popularidade. No entanto, no final do mesmo ano decreta-se extinta, sob a anuênica de seus próprios protagonistas. Com o recrudescimento da repressāo, a prisāo e o posterior exilio de Caetano e Gil, no ano de 1969, encerra-se de vez o ciclo.

Enquanto isso, na Argentina, no mesmo ano de 1968, Manuel PUIG publica seu primeiro romance, La traición de Rita Hayworth. Ambientado na província, de onde se originava o autor, o livro compunha-se de diários, cadernos de pensamentos e redações escolares intercalados aos monólogos interiores dos personagens, que estruturavam a narrativa. Como no Tropicalismo brasileiro, explicitava-se o universo cafona das classes médias. Esse procedimento, que prossegue em Boquitas pintadas, do mesmo autor, publicado no ano seguinte, será ampliado na literatura hispano-americana dos anos de 1970, sendo possível citar quase uma dezena de autores que dão continuidade a esse filāo.

Investigaremos, neste trabalho, as semelhanças entre essas realizaçōes artísticas, contemporâneas em países diferentes, especialmente a partir das letras de algumas cançōes tropicalistas e dos dois romances citados de Manuel Puig, procurando identificar, nessas obras, as matrizes culturais que as informaram, nas suas especificidades brasileira e hispano-americana.

Última data: o boom da narrativa hispano-americana chega ao Brasil exatamente nesses mesmos idos de 1968/69. A editora Sabiá edita em 1969, por exemplo, as traduçōes Antologia pessoal, de Jorge Luis BORGES e Cem anos de solidão, de Garcia MARQUEZ, que rapidamente transforma-se num best-seller. José AGRIPPINO, por essa época, publica o romance PanAmérica. A América Latina, à qual os brasileiros raramente demonstraram consciência de pertencer, estava, portanto, na moda. Será ela a única responsável pela 
temática da latino-americanidade? Celso Favaretto alude ao fato de que este tema surge em apenas duas cançōes tropicalistas: Tres caravelas, de A. ALGUERO e G. MOREAU, que tem a letra original, em espanhol, alternada, na gravação, com estrofes vertidas ao português, e Soy loco por ti, America, de CAPINAM e Gilberto GIL, na qual a mistura das duas línguas é acompanhada da fusāo de ritmos caribenhos. A escolha do tempo arcaico que aparece na primeira letra coincide com a abordagem que a recém-descoberta, no Brasil, literatura hispano-americana fazia da cultura do continente: recriação de um tempo primordial como tentativa de refundar a identidade cultural latino-americana.

No entanto, num país que se modernizava, que despontava como mercado da música popular intemacional, gravar a música popular do Caribe, cuja última memória era o bolero e a rumba tipo-exportação dos anos de 1950, significava trazer à tona o lado passadista, e por isso mesmo, cafona, da cultura latino-americana. A letra de Tres caravelas, em si mesmo galhofeira, indica, além disso, o tom humorístico da escolha. Depois de narrar a chegada de Colombo à América através de um estribilho (Un navegante atrevido / Salió de Palos un día / Iba con tres caravelas / La Pinta, la Niña y la / Santa María / ), o acontecimento arcaico, na penúltima estrofe, atualiza-se num dos temas mais comuns das letras de música popular: o do amor ("Mira tú que cosas pasan / Que algunos años después / en esta tierra cubana / yo encontré a mi querer"), além de desmitificar-se pela atribuição de uma atualidade cronológica ("algunos años después"). $\mathrm{Na}$ última estrofe, o patriotismo reduz-se a interjeiçōes ("Viva el señor Don Cristóbal / Que viva la patria mía / Vivan las tres caravelas / La Pinta, la Niña y la / Santa María"). Na gravação tropicalista brasileira, ${ }^{3}$ a estrofe é assim parodiada: "Muita coisa sucedeu / Daquele tempo pra cá / o Brasil aconteceu / É o maior que há", numa referência clara ao ufanismo que vigorava no nacionalismo retrógrado reeditado pelos militares.

Muito já se disse sobre a paródia tropicalista. Celso FAVARETTO, analisando o procedimento cafona do movimento, conclui que a utilização da paródia nas letras de música do grupo produz "um movimento de descolonizaçāo: a desapropriaçāo de um gosto, de produções, de sentimentos e valores, que correspondem a um passado em crise e sobrevivem apenas na ideologia." 4 Em Tres caravelas utiliza-se uma paródia de segundo grau. A letra cubana já continha uma paródia à História oficial, reduzindo-a às interjeiçōes

${ }^{3}$ Cf. LP R 765.040, Philips, 1968. Tropicála ou Panis et Circenses, do qual fazem parte as músicas cujas letras analisamos.

${ }^{4}$ FAVARETTO, Celso, 1979, p.84 
esvaziadas de conteúdo. A versāo tropicalista parodia essa paródia do primeiro grau, o que, "se desperta atençāo mais para as versōes de que para os significados primeiros", 5 indica, também, a inserçāo do Brasil num procedimento que os setores politicamente conservadores da América Latina sempre foram competentes em promover: mesclar o discurso histórico à exaltação da Pátria. O resultado final, nessa versāo de Tres caravelas, é negar a retomada desse tempo primordial de que haviam partido os novos narradores hispano-americanos. Prefere-se, nela, utilizá-lo para expor, parodicamente, sua apropriaçāo ideológica pelas classes dominantes. Uma lição aprendida, sem dúvida, com a Antropofagia de Oswald de Andrade. A retomada do momento da Conquista Espanhola, através da releitura dos cronistas, de onde parte a renovação operada pela narrativa hispano-americana contemporânea, já estava presente no Modernismo Brasileiro de 22. Mário de ANDRADE a concretizara, também através da paródia, com a Carta prás Icamiabas ${ }^{6}$ (paródia à Carta de Caminha). Antes, Oswald já fizera a paródia a esse mesmo texto em alguns de seus poemas. ${ }^{7}$ A noçāo de diferença latino-americana, tāo cara aos narradores do boom, foi posta, no Brasil, com a Antropofagia. Se essa diferença se coloca, entre os hispano-americanos, como mestiçagem, na visão de Oswald, ela configura-se na deglutição que, transformada em técnica literária, permite a utilização desde a fala coloquial até a incorporação das informações cstéticas aportadas do exterior às nossas cidades em expansão. $O$ resultado é uma abordagem alegórica da naçāo brasileira, cuja imagem se forma pelo fragmento, totalizando-se, apenas, através da articulaçāo dessa diversidade de elementos.

Foi essa a grande aprendizagem que o Tropicalismo fez da Antropofagia. Dela foi extraído o processo desagregador da cultura brasileira que emergia do teatro, do cinema, do texto e da música popular tropicalistas, produtor de uma imagem multifacetada que, ao destruir a lógica linear do nacionalismo a eles contemporâneo, provocou uma mudança de perspectiva na sua apreensão.

Segundo Dante Moreira LEITE, ${ }^{8}$ o nacionalismo no Brasil, enquanto proposta estética, remonta ao Romantismo, quando apresentou-se como forma eficiente de operar, esteticamente, o projeto unificador da Independência. Desde então, nas suas diversas concepçōes, baseou-se sempre na atribuição de traços positivos ao cará-

5 FAVARETTO, p.82.

${ }^{6}$ ANDR ADE, Mário. 1970, p.93-103.

${ }^{7}$ ANDRADE, Oswald. História do Brasil. In:

${ }^{8}$ LEITE, Dante Moreira, 1969. 1971,p. $79 \cdot 90$ 
ter brasileiro, totalizando, com eles, uma imagem positiva do Brasil. De alguma maneira, esses traços persistiam no modelo cultural de 1950. A utopia do desenvolvimentismo reeditava esses traços positivos. Inviável em 1964, a utopia transfere-se para a Revolução Proletária. Alguns críticos, ainda imbuídos dessa utopia, atacaram, no calor do surgimento do Tropicalismo, a visão absurda do Brasil ${ }^{1}$ que ele oferecia.

A letra de Soy loco por ti. America nos aproxima dessas questōes. Em primeiro lugar, a escolha do tema americano sempre ampliou, no pensamento brasileiro, as escalas do nacionalismo estreito. Assim foi com Manoel BOMFIM ${ }^{10}$ no início do nosso século. a quem a inserção política do Brasil na América Latina permite superar a abordagem biológica, calcada na primazia da raça, predominante nos seus contemporâneos. Manœel Bomfim, ao atribuir nosso subdesenvolvimento à exploraçāo levada a termo, em toda a América Latina, pelos povos europeu e norte-americano, antecipa a análise contemporânea da dominação imperialista, a lém de absolver a mestiçagem, valorizada por Bomfim como um ponto positivo, da responsabilidade de nossos males, atribuição, por exemplo, presente em Silvio Romero.

Portanto, se nossa aproximação da letra de Soy loco por ti, America, é feita através da escolha do tema, deve indicar uma imagem positiva do caráter nacional brasileiro. A opinião de Augusto de CAMPOS sinaliza essa direção. Segundo ele, a letra encama o "Tropicalismo anti-Monroe: a América para os americanos." "Nela, fundem-se as línguas portuguesa e espanhola. Metaforizada num ser feminino, a América da letra de Capinam vai sendo descrita nas duas línguas, metonimicamente: da "espuma blanca". ao "cielo", ao "sorriso". a primeira estrofe termina argüindo-lhe o nome enquanto a coloca como "amantel desse país sem nomel" (portanto, ambos sem identidade). As enumeraçōes que caracterizam essa América são sempre um somatório das culturas brasileira e hispano-americana: "esse tango esse rancho/ esse povo dizei-me/." Predominam as imagens da guerrilha e o tom épico, pouco afeito ao humor e à paródia: "Antes que a definitiva noite/ se espalhe em latino américa/ el nombre del hombre es pueblo/." A imagem alegónica final é de tristeza e morte: "Estou aqui de passagem/ sei que adiante/ um dia vou morrer/ de susto de bala ou vício/", e a letra termina decompondo esse ser feminino nas dualidades opostas que caracterizam a diversidade

${ }^{9}$ SCHWARZ, Roberto, 1978, p. 76.

10 BOMFIM, Manol, In: RIBEIRO. Darcy. 1984.

${ }^{11}$ CAMPOS. Augusto de. 1974, p. 150. 
cultural da América Latina (rural/urbano: engajamento/alienaçāo): "eu vou morrerl .. ./nos braços de uma mulher/ .. .l dentro dos braços da camponesa/ guerrilheira manequim/ ai de mim/ nos braços de quem me queira." Essa exposiçāo do nosso desenvolvimento desigual era corroborado pela interpretaçāo de Caetano Veloso. O ritmo caribenho, reforçado pela percussão, se atribuía uma alegria lúdica a essa letra, também expunha, no palco, o mundo cafona, porque fora de moda. Assim visto pela classe média emergente, esse ritmo findava associado, por esta mesma classe, ao subdesenvolvimento de países mais pobres que o nosso. Justaposta ao caráter de protesto político da letra, que denuncia a repressão comum a nossos países, na época, a música de Gilberto Gil contribui para a construção de uma alegoria nada positiva do nosso continente.

As duas outras letras que contêm referência à América Latina reforçam essa imagem. Em Baby, de Caetano VELOSO, os versos: "vivemos na melhor cidade/ da América do Sul/" fecham a última estrofe, antes do estribilho final, composto pela palavra baby, que Ihe dá título, mais a frase I love you, antecedidas do verso "nāo sei leia na minha camisa." A dominação imperialista norte-americana é citada ainda no verso: "você precisa aprender inglês", que abre essa mesma estrofe. A estrutura dessa letra é mais caracteristicamente tropicalista. Através de enumeraçōes de elementos do consumo supêrfluo (margarina, sorvete, lanchonete) estabelece-se uma antítese com o verbo (você precisa) e monta-se a alegoria dominação/consumo. Portanto, mais uma letra de protesto político. Mais uma vez, também, o lado cafona comparece na música, uma balada lírica de "arranjo fácil", composto de citaçōes de música comercial, Diana (cantada por Paul ANKA e Celly CAMPELLO no início da década e neste disco por Caetano) e na interpretaçāo "sensível" de Gal. ${ }^{12} \mathrm{O}$ resultado é, novamente, uma imagem negativa, que denuncia, além disso, a pseudo-superioridade brasileira em relação à América Hispânica assumida pela mesma classe média que era, muitas vezes, o público dessas cançōes.

Portanto, em termos de significado, o Tropicalismo nāo se distanciava tanto assim de seus contemporâneos nacionalistas. A grande novidade era o dado significante dessas cançōes, a forma com que eram apresentadas ao público. Porque enquanto aqueles compunham cançōes onde a negatividade do presente era contraposta à açāo sobre ele, nas letras e, na música, esta atitude se reforçava em ritmos de origem popular e interpretaçōes épicas, que pretendiam reforçar o caráter heróico da nacionalidade brasileira, nas cançōes tro-

12 FAVARETTO, 1979. . 65. 
picalistas, ao contrário, a denúncia não apontava saída, uma vez que expunha, também, as fissuras do próprio público, metalingüisticamente. A última referência à América Hispânica surge, por exemplo. numa letra que iguala o lirismo piegas ao templo máximo da cultura popular cultuada pelos cepecistas cariocas: a Escola de Samba Estação Primeira de Mangueira. Através de imagens oníricas, as "veredas" (conforme o bolero Vereda Tropical) e uma "cordilhcira" surgen "sob o asfalto" onde passa também "a estaçāo primeira de/ mangueira passa em ruas largas", na letra de Enquanto seu lobo näo vem, de Caetano VELOSO. Novamente um tema lírico, aqui parodiado (o conto infantil Chapeuzinho Vermelho), possivel referência a uma paródia anteriormente realizada pela bossa-nova, na música Lobo bobo. de Carlos LIRA e Ronald BÓSCOLI, transforma-se em denúncia da repressāo que campeava por todo o continente sul-americano, expressa. sobretudo na metonímia "vamos por debaixo. das/ bandeiras, das botas/. A música, uma cantiga infantil, mais uma vez introduz a contradiçāo. Diz Celso FAVARETTO: "Enquanto Caetano canta, com seu característico modo descritivo, "realista", o arranjo vai fazendo contrapontos gaiatos gerando ambigüidade."1/3

Note-se que, para reforçá-la, contribuía o corpo magro do cantor, a esta altura já encarnado em astro a quem tudo é permitido, recoberto de adereços, algumas vezes em trajes femininos, rebolando "sem comedimento". 14 O produto final, fica, além de ambíguo, carregado de uma agressividade em tudo semelhante à que podia ser detectada nos espetáculos do Teatro Oficina.

Para melhor compreender o sentido desse resultado, teremos que buscá-lo no trabalho daquele que foi, segundo Waly SALOMĀO, o "feiticeiro" da Tropicália: Hélio Oiticica. ${ }^{15}$ Se nāo se pode falar de influências, uma vez que o contato com Oiticica, por parte dos baianos, foi concomitante ao reconhecimento deles pelo circuito cultural Rio/São Paulo, pode-se afimar que, sem dúvida, houve um encontro de propostas, as quais, uma vez intercambiadas, passam a correr juntas. Senāo vejamos: Oiticica, à época desse contato com os produtores de música popular, encontra-se na fase em que mais claramente se delineia, na sua obra, o enfoque das particularidades da nossa cultura. O construtivismo, a que nunca negou $\mathrm{fl}_{1}$ delidade, legara à Oiticica o tratamento do espaço, evoluindo dos objetos (Bólides) aos ambientes (Parangolés), que afinal deságuam

${ }^{13}$ FAVARETTO, P.68

${ }^{14}$ SANTIAGO. Silviano, 1978.p. 151

IS SALOMAOO. Waly. A praia da Tropicália. In: SAFFIOTI FIL.HO. Joséct al. $1987 \cdot$ p. $32 \cdot .35$ 
na intervenção Tropicália. Associado à vivência, que o persegue desde o neoconcretismo, produz-se, na obra de Oiticica, o envolvimento do espectador com a obra. A sua novidade, a partir daí, é a concepçāo do espectador-participador. Com ela, Oiticica pretendia atingir a antiarte, onde o artista passa a ser um motivador para a criação, processo dinâmico que envolve criador e espectador. Aliadas à máxima intensidade da figuração, conseguida, na Tropicália, pela exposição das imagens óbvias do exotismo e da tropicalidade, em conjunto, essas propostas provocam a desconstruçāo das referências culturais do espectador e do próprio artista. Ao experimentar as sensações visuais, tácteis, sonoras e olfativas que compóem o labirinto da Tropicália, o espectador vivencia as contradiçōes de nossos referenciais culturais, configurando-se uma obra total que, no entanto, nāo produz uma idéia totalizadora do Brasil. Ao contrário, o resultado dessa vivência é, para o espectador, a indeterminação e a ambivalência.

Estava subjacente nessa proposta a concepção negativa da cultura brasileira, sintetizada na metáfora da diarréia, com a qual Oiticica procura definir a sua oposição às idéias nacionais-populares de seus contemporâneos. Recusando-se ao protecionismo da "cultura popular", como forma de resistência à invasão cultural estrangeira que caracterizava, por exemplo, o ideário do Centro Popular de Cultura (CPC), Oiticica opta, em relação ao mesmo problema, pela relativização cultural, que já vinha praticando desde os Parangolés. Capas coloridas, eles só ganhavam movimento através das evoluçōes dos passistas da Mangueira, levados ao Museu de Arte Moderna especialmente para vesti-los. Esboçava-se, nos Parangolés, a visāo da cultura brasileira como confronto de fatos culturais oriundos de diferentes classes sociais, sempre organizados de forma festiva ou carnavalesca. No entanto, a fruição da festa nāo produzia a positividade que emanava, por exemplo, das obras da intelectualidade oficial, quando muito calcada na solidariedade de dois grupos sociais "puros" - o do "povo" e o dos intelectuais. O resultado alcançado com a obra de OITICICA é uma tensāo permanente, explicitação, segundo ele, da "merda" ( $\mathrm{sic}$ ) em que estava mergulhada a cultura brasileira, concretude muito distante do modelo unitário e positivo que defendiam os "cepecistas".

Não há dúvida de que esta é a opçāo que abraçam os tropicalistas da música popular. A geléia geral, metáfora cunhada por Décio PIGNATARI e comelata à da diarréia, utilizada como título de uma canção modelar de Gilberto GIL (Geléia geral, 1968), ${ }^{16}$ não se

16Cr. L.P Tropicilia ou Panis et circenses, 1968. 
restringia à música. A canção tropicalista era, sobretudo, um evento. onde a vivência do espectador, no sentido em que a conceituara Hélio OITICICA, permitia variadas decodificaçōes do que acontecia no palco. Ao mesmo tempo, se explicitava, metalingüisticamente, na mesma festa que eram suas apresentaçōes musicais, os diversos repertórios de onde eram extraídas as imagens. Estas tinham origem, também, na vivência dos próprios artistas, recém-chegados $\mathrm{da}$ província, cujo repertório musical havia sido adquirido em grande parte pelo rádio e por outras formas pouco conspícuas de cultura. como confessava Caetano VELOSO:

Nunca ouço música erudita, mas a música de rádio sempre me apaixonou. 17

Nós vibrávamos com Buñuel e nos envergonhávanios do prazer que nossos patricios sentiam ao veren as chanchadas da Atlantida e os filmes de Mazzaropi. muito cmbora nảo perdèssemos unı só. 18

Mais tarde, Caetano reiterará em várias letras a sua condiçäo de "mulato", atestado da vivéncia da mestiçagem que é analisada. em relaçāo à Gilberto Gil, por António RISÉRIO:

Nesse sentido. uma composiçāo como Ele falava missos tollo dia deve ser vista nāo apenas enquanto crônica nordaz de una dimensảo tragicamente alienada do modus rivendi classe média. mas também, de uma ótica mais particularizante, assestada na própria trajetória existencial de Gil. como uma espécie de impiedoso réquiem para um "preto exemplar". 19

Também nessa direçāo os baianos chegavam carregados de vivência, encamando o próprio gesto, no sentido que BRECHT/ BENJAMIN ${ }^{20}$ atribuem ao termo, do Brasil de então.

17VELOSO. Caetano. In: CAMPOS. Augusto de. 1974,p. 189

18 Idem Apud. SANTIAGO. Silviamo, 1978. p. 149

19 RISÉRIO. Antonio, 1982. p. 265.

${ }^{20}$ BENJAMIM. Walter, 1987, p.215.216 
Os poetas concretos, fiéis ao seu modelo de superaçāo do subdesenvolvimento, admiraram nos baianos a leitura cosmopolita que empreendiam da realidade brasileira, identificando-os na "excepcionalidade" em relaçāo à nossa cultura ${ }^{21}$ que os fizera distingüir, antes, Oswald de Andrade. Antônio RISÉRIO lembra que 'Em 1966, Augusto de Campos já contestava o coro esquerdista, realçando o que havia de "informaçāo nova" e de virtude estética na Jovem Guarda, enquanto fazia restriçōes à "musica de protesto". Ora, se "poucos entenderam o recado",22 dentre estes certamente deviam estar os baianos, que, ao irromper no cenário com suas guitarras elétricas, nāo eram mais, nem só baianos, nem só negros ou mulatos. Dialogando, também, com a mais fina tradiçāo musical popular brasileira - a bossa-nova -, tentando recuperar dela as informaçōes musicais de validade internacional, Caetano Veloso e Gilberto Gil logo se integraram no clima experimental do setor erudito da nossa cultura. Letras como Batmacumba (1968), poema concreto que bem poderia ter sido assinado por um dos poetas concretos apulistas, indicam o intercâmbio já assimilado e que estará presente na obra posterior de Caetano Veloso.

No entanto, nenhuma dessas vertentes pode ser considerada predominante. O Tropicalismo as incorpora de uma só vez e a totalidade que o caracteriza indica a sua filiação a uma estética moderna, último grito da vanguarda nestas terras de Pindorama que, esteticamente, nunca mais foram as mesmas. Sobretudo porque o movimento alterou a concepção de gosto artístico que, exceptuando-se o Modernismo, havia permanecido, no Brasil, na esfera de um bomgosto cujo modelo eram as artes eruditas européias. Cremos que o Tropicalismo possibilitou um processo muito bem descrito por Carlos ZíliO: "A questāo da arte brasileira é deslocada de um modelo para uma situaçāo concreta, determinada pela inserção da obra numa cultura particular." 23

Cultura que a Tropicália revelaria como disparidade e contradição, movida, não só por todas as influências antes captadas pelo Modernismo, mas também pela cultura midcult introduzida a todo vapor no Brasil pela mídia. O resultado é um conjunto anárquico, construído com a cópia e com o kitsch, mimetizado, principalmente, nos cenários dos espetáculos tropicalistas e na roupa de seus astros, como relembra Regina BONI, responsável pela concepção do figurino dos shows:

\footnotetext{
${ }^{21}$ MARTINEZ, Agustín A., 1989, p.6-7

22RISÉRIO, Antonio, 1982, p. 260.

${ }^{23}$ ZÍl,jO, Carlos, 1982.p.45.
} 
Tinha a impressão exata de copiar. Mas o que eu fazia era apenas retirar formas e imagens do inconsciente coletivo: vieses de Jane (sic) Harlow, cetim da década de 30 , fitas de quarenta, tecidos de formar caixinhas de música (. . . ), boás de plumas, (. . .), malhas de metal. Peles - nāo de vison, mas de coelho e tintas de anilina rosas, amare as, roxas. Jerseys drapeados, violetas, (. . . .), plástico fazendo papel de couro, (. . . .). feltro no lugar de casimira inglesa, (. . . ), tecido de fibra de banana bordados com fios de prata que era fabricado nas Filipinas. 24

Desse mesmo inconsciente coletivo parte Manuel Puig para construir seus romances. Mas, ao invés de cetim, PUIG arrebata, no romance La traición de Rita Hayworth. ${ }^{25}$ de 1968 , os filmes dos anos de 1930 por inteiro. Num processo estruturador que será retomado num romance bastante posterior ( $E l$ beso de la mujer araña, de 1976), os filmes dos anos de 1930 e 1940, narrados, principalmente pelo protagonista Toto, introduzem, no romance argentino, o universo da cultura média, com toda a sua carga de gosto duvidoso. Neste primeiro romance, ele se agrega à descrição da vida na província, onde a estória é ambientada. Ainda atrelado ao modelo do romance europeu e norte-americano, o narrador confina o mau-gosto ao interior dos extensos monólogos interiores que estruturam a narrativa, embora a banalidade presente no longo diálogo que compōe o primeiro capítulo - entre duas personagens femininas, enquanto se ocupam de bordar toalhas - situe o leitor no mundo privado e na atmosfera provinciana marcada no romance, principalmente, pela paródia. Nos capítulos finais, citando parodicamente diários femininos, cademos de pensamentos e cartas familiares, o narrador de $L a$ traición explicita a mediocridade que amarga a vida dos personagens, possibilitando a apreensão alegórica de uma imagem negativa do seu mundo.

O romance atualiza, tambem, uma questão central na cultura argentina: a da oposição entre a Buenos Aires metropolitana e cosmopolita e a anacrônica província argentina, metaforizada, nesse livro, na cidadezinha de Coronel Vallejos. A questāo, que no século XIX apresentava-se sob a forma de campo/cidade e civilização/barbárie, parece, com o romance de Puig, atualizar-se, ainda, em subúrbio/cosmópole. Porque mesmo na grande urbe encontra-se

${ }^{24}$ BONI, Regina. Pano costurado. In: SAFF IOTI FILHO. José et al. 1978, p. 57. ${ }^{25}$ PUIG. Manuel. 1971 
essa oposiçāo entre cultura média e cosmopolitismo, como fica evidenciado no capítulo Diário de Ester (p.218-243), através da paródia aos diários das adolescentes. Iniciado com imagens gastas: "Ya se va el domingo, con su bagaje de doradas promesas, y las promesas no cumplidas. . . de noche no brillan más, como mi broche de lata" (p.218), que também marcam a oposição subúrbio/grande urbe: "Ya cayó la noche en mi suburbio, aś como en la esquina más aristocrática de la urbe porteña, para todos se ha puesto el sol, uno de tantos consuelos del pobre.", o capítulo introduz um tema novo na abordagem da cidade de Buenos Aires. À "cultura de mezcla" que, segundo Beatriz SARLO, ${ }^{26}$ caracterizou a fase de sua maior expansão urbana, correspondem os personagens de Roberto Arlt. A posição de Ester, ao contrário da marginalidade que caracterizava os personagens daquele autor, revela uma coexistência entre uma cultura de primeira māo, a da "elegante avenida arbolada" (p.241) e uma de segunda, a do subúrbio, que oferece aos pobres apenas consolos. Note-se que Umberto ECO, ao analisar a cultura organizada pela indústria cultural, afirma que a sua aceitaçāo entusisástica por parte do público deriva do fato de que os produtos dessa indústria funcionam, justamente, como "estruturas de consolaçāo." 27

Também dessa forma eles aparecem em La traición de Rita Hayworth. No capítulo "Mita, Invierno, 1943", os enredos dos filmes americanos consolam a personagem da morte de seu bebê recém-nascido (p.136-154). No capítulo "Toto, 1942" (p.69-96), propiciam ao protagonista evadir-se de um ambiente hostil ou de lembranças indesejáveis.

A programaçāo de rádio, por outro lado, evidencia a presença de gostos distintos e diferenciação no seu atendimento por parte da indústria cultural. As estaçōes comerciais são "tangueras" e têm sua audiência assegurada no interior graças ao seu investimento em "antenas fuertes" (p.270). À cultura erudita, cujos consumidores, em Coronel Vallejos, restringiam-se a Toto e sua professora de piano, restava a transmissāo da Ópera do Teatro Colón, de Buenos Aires, aos domingos, "la única transmisión del Colón que se hace por onda corta y que se puede escuchar en Coronel Vallejos." (p.277), embora competindo com a transmissão, no mesmo horário, das partidas dominicais de futebol.

O romance seguinte de Puig tem como personagens os ouvintes dessas estaçōes tangueiras. Também ambientado em Coronel Valle-

${ }^{26}$ SARLO, Beatriz, 1988, p.15

${ }^{27}$ ECO. Umberto. A pacakpricos e integrados. In: BOSI, Eclé. Cutura de massa, cultura popular, cultura operária. 1977, p.53-83, 72-73. 
jos, seu título - Boquinhas pintadas ${ }^{28}$ - é extraído de um tango famoso e também são versos de tangos antológicos as epígrafes de cada capítulo que recebem, em espanhol, o título de entregas (fascículos), marcando a incidência da paródia sobre outro produto da indústria cultural - o folhetim. Este está presente, também, na construção arquetípica dos personagens, na visăo maniqueísta de que se reveste a relação entre pobres e ricos e na linguagem kitsch que constitui, por exemplo, as cartas da seçāo Correio do coraçāo.

O rádio comparece no $13^{\circ}$ fascículo, reduplicando o diálogo entre as duas pontas femininas do triângulo amoroso que compōe o enunciado, no momento de seu clímax, através da paródia a uma novela, que se interpōe entre as falas das duas mulheres.

Se no Tropicalismo brasileiro, a interpretaçāo fria e despojada de Caetano Veloso desrealiza as cançōes de Vicente Celestino, ${ }^{29} \mathrm{em}$ Boquinhas pintadas, a apresentação marcada por datas e horas ("Na mencionada quinta-feira, 23 de abril de 1937, Maria Mabel Sáenz, conhecida por todos como Mabel, abriu os olhos às 7,00 da manhā, quando seu despertador de marca suíça começou a tocar." - p.60), ou a descrição de uma festa popular à maneira de um relatório (p.82-83, Sexto fascículo), colocam o narrador à distância do narrado, oferecendo ao leitor, por esse processo, o mesmo distanciamento. Como no Tropicalismo, exige-se o leitor-participador. Mas, enquanto no Tropicalismo a participaçāo estava mais próxima da absorção de técnicas vanguardistas que compunham as letras das cançōes, a participaçāo do leitor, em Boquinhas, parte de outro princípio. Consiste em identificar os diversos repertórios de que é composto o intertex to do romance, acrescentando-lhes, e neste ponto aproxima-se mais do Tropicalismo, as suas próprias vivências de cada um deles.

Ou seja, no Tropicalismo o mau-gosto aparecia como um contraponto, como citaçāo, no interió de uma èstrutura que era, em profundidade, vanguardista. O mesmo acontecia, de certo modo, com La traición de Rita Hayworth. Boquinhas vai mais longe nessa apropriaçāo do mau-gosto. Ao ponto de compor-se de sua citaçāo, através da paródia. Romance construído com o lugar-comum, Boquinhas reduz a questāo argentina ao universo das classes médias. Vivência que, nos romances argentinos imediatamente anteriores, nāo tinha lugar. Metafóricos, esses romances, cujo exemplo maior é Rayuela, de Julio CORTÁZAR, desenhavam uma Argentina utópica, estruturada através de personagens individuais e problemáti-

28 PUIG, Manuel, 1976.

${ }^{29}$ FAVARETTO. 1979, p.65. 
cos, cujo destino apontava simbolicamente para o mundo público.

Puig inicia sua carreira literária reduzindo a esfera do enunciado para o mundo privado. Alegóricos, seus primeiros romances nos apresentam fragmentos da vida doméstica de personagens tipificados e arquetípicos, compondo a imagem de uma cultura imitada e postiça.

A idéia da cultura latino-americana como imitaçāo ou cópia é um dos pilares da elaboração de nossa identidade cultural. Produto de um sentimento de inferioridade, que resulta da atribuição de um "prestígio ideológico dos países que nos servem de modelo", 30 a cópia pressupōe uma imagem negativa da cultura latino-americana. Parece ser esta a feição desenhada tanto pelo Tropicalismo quanto pelos romances examinados de Manuel Puig. Embora alinhados, nos dois casos, ludicamente, de forma metonímica, os diversos textos que explicitam a cópia terminam por configurar uma alegoria nacional que, se no Tropicalismo pode ser traduzida como uma contradiçāo insolúvel entre anacronismo e avanço, parece reduzir-se, nos romances de Puig, a um anacronismo sem remédio.

A questão da alegoria nacional é a imagem central da abordagem que Jameson faz das literaturas do Terceiro Mundo. JAMESON parte do princípio de que, para nossas culturas, é impossível a concepção de autonomia, uma vez que nos mantemos "embolados numa luta de vida ou morte com o imperialismo cultural do Primeiro Mundo."31 A partir daí, analisa nossos tex tos como derivaçōes periféricas, premidos entre a pós-modernidade que atravessa os países do Primeiro Mundo e o nacionalismo, que parece a Jameson a única possibilidade de escapar desse determinismo.

Aijaz AHMAD, em resposta ao artigo de Jameson, esclarece que sua visão, ao tentar totalizar o Terceiro Mundo, termina por atribuir à nossa produção cultural uma determinação unitária e homogênea. A ela contrapõe uma postura crítica que permita "localizar a produçāo de textos dentro de um campo de poder e significação determinado." 32 Essa abordagem seria a única forma de escapar da idealização que, segundo ele, perpassa a análise de Jameson.

Se nos ativermos à abordagem de Roberto Schwarz, podemos dizer que o artigo de Jameson nos devolve, do ponto-de-vista do Primeiro Mundo, a utopia de uma latino-americanização da sua cultura, presente nas abordagens de muitos críticos latino-americanos. Foucault e Derrida, segundo Schwarz, oferecem, nessas abordagens,

\footnotetext{
${ }^{30}$ SCHWARZ, Roberto, 1989, p. 30.

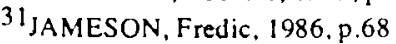

32 AHMAD, Aijaz, 1988, p.178.
} 
0 instrumento teórico que possibilita transformar a inferioridade em superioridade, a cópia em originalidade.

Da mesma forma, apressadamente importam conceitos como o da pós-modernidade que, como vimos com Ahmad, terminam por reiterar nossa dependência cultural. Como esse crítico também ressalta, é possível detectar traços da pós-modemidade em nossa literatura. A eliminação da interioridade e a conseqüente superficialidade, a negaçāo da totalidade, a narratividade do privado em detrimento do público, são evidentes características pós-modernas de Boquinhas pintadas. Assim como a ânsia de totalizaçāo, a ruptura da lógica linear e a crítica da ordem social são traços modernos do Tropicalismo.

No entanto, é mais importante ressaltar o diálogo travado por esses artistas com a história da elaboraçăo de nossa identidade cultural. Reiterar a resposta tropicalista ao modelo nacional-popular de seus contemporâneos, concomitante à retomada da tradição internacionalista da Antropofagia e da bossa-nova.

Manuel Puig, por sua vez, chegava à literatura argentina como epígono do boom que, se por um lado atualizara a literatura hispano-americana com as técnicas internacionais, possibilitando uma fruiçāo universal de seu texto, por outro construíra a imagem positiva, de matriz utópica, da cultura do continente, calcada no modelo abstrato de uma origem que, se mitificava o passado, parecia não ter mais talento para atingir o presente. Na Argentina, especificamente, este se apresentava, na maioria dos casos, como o exnlio, caminho seguro para esses escritores que conheceram, pela primeira vez, na América Latina, o gosto da aprovação internacional, traduzida em vendagem nunca antes experimentada pela literatura do continente.

Nesse sentido, os artistas de 1968, como já vimos com Carlos Zílio, desenham a situaçāo concreta da nossa cultura, desvinculando-a do modelo abstrato da utopia. Traçado com a vivência do mau-gosto, o desenho deixa a nu as contradições de nossa configuração social, aclarando, mais do que nunca, o fosso que separa a fruição cultural dos mundos sociais opostos que a compōem.

\section{RESUMO}

O movimento Tropicalista brasileiro (1968), não só é contemporâneo aos primeiros romances do escritor argentino Manuel Puig (A traição de Rita Hayworth, de 1968 e Boquinhas pinta- 
das, de 1969), mas tamberm utiliza processos formais semelhantes. como a incorporaçāo do mau-gosto e de cultura média ao texto erudito, enfoque inovador do velho dilema, presente na arte e no ensaio latino-americanos, entre a originalidade elou a cópia da nossa cultura.

\section{REFERÊNCIAS BIBLIOGRÁFICAS}

1 AHMAD, Aijaz. A retórica da alteridade de Jameson e a "alegoria nacional". Novos estudos. Cebrap, Sāo Paulo, v.22, p.157-81.

2 ANDRADE, Mário. Macunaíma. 6. ed. São Paulo : Martins, 1970.

3 ANDRADE, Oswald. Poesias reunidas. Rjo de Janeiro : Civilização Brasileira, 1971. v.7.

4 BENJAMIN, Walter. O que é o teatro épico? (Primeira e Segunda Versāo). In: KOTHE, Flávio R. Benjamim e Adomo: confrontos. São Paulo : Ática, 1978. p.202-218.

5 Documentos de culura, documenuos de barbárie: escritos escolhidos. São Paulo : Cultrix; Editora da Universidade de São Paulo, 1986.

6 BOSI, Ecléa. Culiura de massa e cultura popular Leituras de operárias. 4.ed. Petrópolis : Vozes, 1977.

7 BRITO, Antonio Carlos de. Tropicalismo: sua estética, sua história Revista Vozes, Rio de Janeim, v.66, n.46, p.21-30, 1972.

8 CALDAS, Waldenyr. Acorde na aurora. Música sertaneja e indústria cultural. São Paulo: Nacional, 1977.

9 . A utopia do gosto. São Paulo : Brasiliense, 1988

10 CAMPOS, Augusto de. O balanço da bossa. São Paulo : Perspectiva. 1974.

11 Poesia, antipoesia, antropofagia. São Paulo : Cortez \& Moraes, 1978.

12 DOSSIÊ Música brasileira. Revista USP, Sāo Paulo, v.4, p.84, dez./jan. $1989 / 90$.

13 ECO, Umberto. Apocalípticos e integrados. Sāo Paulo : Perspectiva, 1976.

14 FA VARETTO, Celso. Tropicália, alegoria, alegria. São Paulo: Kairós, 1979. 
(Doutorado) - Faculdade de Filosofia, Letras e Ciências Humanas, Universidade de Sảo Paulo.

16 A música nos labirintos de Hélio Oiticica. Revista USP. São Paulo, v.4, p.45-54, dez./fev. 1989/90.

17 HELENA, Lucia. Totens e tabus da modernidade brasileira: símbolo e alegoria na obra de Oswaild de Andrade. Rio de Janeiro: Tempo Brasileiro; Niterói : Universidade Federal Fluminense, 1985

18 HOLLANDA, Heloísa Buarque de. Impressöes de viagem: CPC, vanguarda e desbunde: $1960 / 70$. São Paulo : Brasiliense, 1980.

19 HOLLANDA, Sérgio Buarque de. Raíes do Brasil. 18.ed. Rjo de Janeiro : José Olympio, 1986.

20 JAMESON, Fredic. Third-Word literature in the era of multinational capitalism. Social Text, v.15.65-88, 1986.

21 JENCKS, Charles. What is post-modernism? London : Academy Editions, 1986.

22 KING, John et al. Modern Latin American fiction: a survey, London : Faber and Faber, 1987.

23 LEITE, Dante Moreira. O caräter nacional brasileiro. 2.ed. rev. amp. Sāo Paulo: Pioneira, 1969.

24 LOBO, Edu et al. Confronto: música popular brasileira. Revista Civilizaçāo Brasileira, Rio de Janeiro, v.1. n.3. p.305-12.

25 LYOTARD, Jean-François. O pós-moderno. 3.ed. Rio de Janeiro: José Olympio. 1988.

26 MARTINEZ A., Agustin. De seqüestros e revisōes (uma questāo de historiografia literária). O Estado de Säo Paulo, 30 dez. 1989 Suplemento Cultura, c. 1-6, p.6-7.

27 MEDINA, A.C. de. Música popular e comunicaçāo. Um ensaio sociológico. Petrópolis : Vozes, 1973.

28 OITICICA, Hélio. Aspiro ao grande labirinto. Rio de Janeiro : Rocco, 1986.

29 PEREIRA, Carlos Alberto Messeder. Retrato de época: poesia marginal, Anos 70. Rio de Janeiro: FUNARTE, 1981.

30 PEREIRA, Carlos Alberto Messeder: HOLLANDA, Heloísa Buarque de. Patrulhas ideológicas. São Paulo: Brasiliense, 1980.

31 PERRONE, Charles. Poesia concreta e tropicalismo. Reviska da USP. São Paulo, v.4, p 55-64, dez./fev. 1989/90. 
32 PUIG, Manuel. Latraición de Rita Hayworth. Barcelona: Seix Barral. 1982 .

33 Boquinhas pinadas. 2.ed. Rio de Janeiro : José Olympio,

34 RIBEIRO, Darcy. Manoel Bonfim, antropólogo. Revista do Brasil. Rio de Janciro, v.1, n.2, p.48-59, 1984.

35 RISÉRIO, Antonio, Posfacio: Gil Brasil Bragil uma apreciaçāo didática, In: GIL, Gilberto. Expresso 2222. São Paulo : Corrupio, 1982.

36 RODRIGUEZ MONEGAL, Emir. Los sueños de Evita: a propósito de la última novela de Manuel Puig. In: América. Buenos Aires: Alfa, 1974 Narradores de esta

37 SAFFIOTI FILHO, José et al. Tropicuilia, 20 anos. Sāo Paulo: SESC, 1987.

38 SANT'ANNA, A fonso Romano de. Misica popular e moderna poesia brasileira. Petrópolis: Vozes, 1978.

39 SANTIAGO, Silviano. Uma literatura nos trópicos: ensaios sobre dependência cultural. São Paulo : Perspectiva, 1978.

40 SANTOS, Lidia do Valle. Manuel Puig, ou a maldição de narrar. In: CÁRCAMO. Silvia et al. A literatura argentina contemporânea. Rio de Janeiro : Instituto Cultural Brasil-Argentina, 1985. p.24-28.

41 SARLO, Beatriz. Una modernidad periférica: Buenos Aires 1920 y 1980. Buenos Aires : Nueva Vision. 1988.

42 SCHWARZ, Roberto. As idéias fora do lugar. In: vencedor as halutas. São Paulo : Duas cidades. 1977. Ao . Cultura e política, 1964-1969 Alguns esquemas. In: Terra. 1978. p.61-92.

44 Nacional por subtraçāo. In: Paulo : Companhia das Letras, $1987 \overline{. p .29-48}$ Que horas são? Sāo

45 SODRÉ, Muniz. Teoria da literutura de massa. Rio de Janeiro : Tempo Brasileiro, 1978.

46 SUSSEKIND, Flora. Notas sobre D. Arrigucci e R. Schwarz. Novos estudos. Cebrap, Sāo Paulo. v.20.p.96-109, mar.1988

47 VASCONCELLOS, Gilberto. Muisica popular: de olho na fresta. Rio de Janeiro : Graal, 1977.

48 ZÍllO, Carlos. Da Antropofagia à Tropicália. In: ZILIO, C. et al. $O$ 


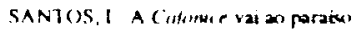

nacional e popular na cultura brasileira: Artes plásticas. Sāo Paulo B rasiliense, 1982, p.13-56. 